\title{
Hypnoparenting Training in Improving Parent's Ability About Parenting
}

\author{
Wasmin, Achmad Hufad, Ace Suryadi, Oong Komar, Dadang Yunus Lutfiansyah
}

\begin{abstract}
Hypnoparenting is an alternative model of parenting aiming directly to the subconsciousness which is the centre of emotion obstacles felt by parents. This research aimed to obtain concrete description of hypnoparenting training, started from the planning, implementation, evaluation, and participant assistance pattern after the training. This research applied qualitative descriptive method. The data were collected through observation, interview and documentation study to six respondents which were paricipant, committee, parents, and training manager. The result of this research showed that (1) the planning did not conduct fully as it has to. The planning was handled by resource person. (2) Resource person was the key role to the implementation of TANDUR (Tumbuhkan-Growing, Alami - Experiencing, Namai - Naming, Demonstrasikan Demonstrating, Ulangi - Repeating, Rayakan - Celebrating) model. (3) Evaluation, this training was lack of content and context, and only a participants' testimony. (4) The assistance after the training was good based on GROW (Goal, Reality, Option, and Will) pattern.
\end{abstract}

Keywords: Training, Hypnoparenting, Parenting

\section{INTRODUCTION}

Nowadays, education had narrow meaning in the society. Education was only linked to schools. Whereas, schools were limited by age. This narrow meaning implied that education was only for children in their school age, while the adult did not need it. As the time goes by, life become more complex and growing, as well as the parenting. Children in the past and today's children were different in term of their demands, such as the behavior, attitude, knowledge, and skill.

The motivation to learn for the adults was supported by lifelong learning concept as in the Indonesian Law about National education system UU No. 20 Tahun 2003 section IV subsection 5 article 5 stating that every citizen has the right to have the opportunity to improve lifelong education [1].

Revised Manuscript Received on September 22, 2019.

Wasmin, Universitas Pendidikan Indonesia, Bandung, Indonesia. Email: wasmins3@student.upi.edu

Achmad Hufad, Universitas Pendidikan Indonesia, Bandung, Indonesia. Email: achmadhufad@upi.edu

Ace Suryadi, Universitas Pendidikan Indonesia, Bandung, Indonesia. Email: acesuryadi@upi.edu

Oong Komar, Universitas Pendidikan Indonesia, Bandung, Indonesia. Email: oong.komar@upi.edu Universitas Pendidikan Indonesia, J1. Dr. Setiabudhi No. 229, Bandung, Indonesia. Email: dadangyunus@upi.edu
Dadang Yunus Lutfiansyah, Community Education Department,

Parents' learning motivation is expected to produce strong generation to cope with the worlds' change, instead of a generation that is weak and unbehaves. A hadits suggested that "every child was born with their nature until they become fluent (in speaking), so their parents will lead them to be a Jewish, Christian, or Magi" (Ath-Thabarani, 1983) [2]. Therefore, there should not be unbehaved children if their parents have educated them properly as their nature.

In fact, many parents complained about their children who were disobedient, undisciplined, timid and lack of confidence, victims of bullies, decreased performance, addicted to games, dropped out of school, running away from boarding schools, anxious, afraid, careless, lying, stealing, whiny, to wet the bed, stress, phobia, aggressive, negative emotions, and other bad behaviors.

It was not only parents' problems, throughout 2011, National Commission for Child Protection in Jakarta received about 200 case reports per month. It was increasing to $98 \%$ from the previous year (Sirait, 2012). [3] These reports indicated the escalation of stress disorder of Indonesian children. Signs of the preschoolers experiencing mental stress that exceeds their strengths are: more irritable, experiencing nightmares, rude, being more stubborn or demanding or even crying more often than usual.

Sirait (2012) [3] stated that there was increasing number of children who encountered stress disorder with various reasons. National Commission for Child Protection recorded $82.9 \%$ of the cases caused by the lack of communication between children and parents. It was an irony because parents hold the most important role in children's character buiding. Parents are rightful to decide the education for their family. The family is the oldest and most basic institution of all human institutions. Family built both culture and character. From family culture someone is formed. From family also someone is born and grows with his character. It is meaningful for family life.

Building the nation was started from building a good family. It has to be understood by parents for them to produce a strong generation, instead of a weak generation. It was stated in the Mushaf Al Qur'anul Kariim, Miracle the Reference (2010): And let Allah fear those who leave the weak children behind and worry about (their welfare). Therefore, they should obey Allah and say the right words. (pp. 153) [4]. 


\section{Hypnoparenting Training in Improving Parent's Ability About Parenting}

Weak generation was caused by weak character. Lickona (2012) [5] simply defined that character is "what you do when no body's looking". Good and strong character would stay good even if nobody saw them. The role of the family is vital in building a strong character.

Unfortunately, the vital role of family did not accompanied by parents' understanding of effective parenting. Greenberg, M. (2012) [6] stated "...avoid ineffective ways of communicating that lead to noncompliance and power struggles, or damage self-esteem." The ineffective way of communicating by parents led to violations and power struggles, or damage to self-esteem.

According to him, there are four common mistakes that parents make in communicating with their children. The first is that parents talk too much. The second is that parents repeatedly nag and warn their children. The third is that parents use guilt and shame of the children to be obedient. The forth is that parents does not listen to children emphatically.

In addition, parents doubtly give punishment to their children when they are unbehaved and seldom give some reward to appreciate simple improvement. Parents have less understanding about the stafe of developmental age and inconsistent in some ways. It caused they have weak position in front of their children. The different perspective of parenting by mother and father also often happened.

There were some ways to improve the understanding of parents about effective parenting, such as Majelis Taklim, counseling, seminar, and training. Parenting training is currently very popular with various names, for instance Quantum Parenting, Efektif Parenting, ESQ for Parenting, parents' school, mother's school, and hypnoparenting training as Yayasan Anak Langit frequently conducts.

According to Lilis Komariah, as psychologist and speaker in Yayasan Anak Langit, parent seminars and training are ineffective because it only touches the side of parental knowledge from the aspect of effective parenting concept. Moreover, the obstacles in parenting are not only from the children but also from the parents as well. Obstacles from parents which are quite challenging turned out not from less understanding of parents, but there are factors that are more emotional or parental feelings.

From the interview with a psychologist in Yayasan Anak Langit, Lilis Komariah, she stated that there are seven obstacles for the parents in parenting process, they are: first, the fear of losing their child; second, the worry of losing affection from their children; third, the worry of their children's future which make them overprotective, fourth, the feeling of owing the times for their children and redeem it with material. Fifth, the revenge of their past. Sixth, the rejection of the child's birth which led to guilty feeling. Seventh, bad culture of family and bad leadership.

Those previous emotional obstacles sourced from parents' subconsciousness. Although, they totally realized that their parenting was not proper, the obstacles from their subconsciousness controlled the feeling. This kind of obstacle cannot be cured with basic seminars or training. It needs seminars or training which can touch their subconsciousness and give them meaningful understanding and lead to effective parenting.
Based on the explanation, the researcher were interested in reviewing about hypnoparenting training in impoving parents' parenting ability which was conducted in Yayasan Anak Langit Bandung.

\section{LITERATURE REVIEW}

Hypnosis or hypnotherapy, initially used in the medical field or medical, developed and expanded into the world of parenting education through the concept of hypno-parenting. Growing evidence has continued to show that although there is no scientific evidence to prove the claim that hypnosis is a wonderful parenting tool, many have found it useful [7]. According to Lisa Machenberg as cited by Spooky (2016) if parents learn hypno-parenting, they can learn how to hypnotize their children to be cooperative, peaceful, have containment and are in position to develop good study habits which enables them to be focused and more resilient in the broader society [7].

Hypno-parenting is a development of neurohypnosis, and the term neurohypnosis was first suggested in the mid 1800s by James Braid, an English surgeon, based on his belief that a state of hypnosis was related to sleep. Thus, he based the term on the Greek Hypnos (sleep). As he further studied hypnotic phenomena, Braid developed the view that hypnosis involved a subject's focus on a single idea. [8]. Hypnosis exists since the beginning of humanity and is an integral part of our daily life. Hypnosis affects the subconsciousness, which is the center of emotions, habits and automatisms.[9]. It can eventually have desirable changes at the following levels: motivation, self-image, habits, style of living, health, perception, way of thinking, behavior, in addition to a modification of physical sensations.[10].[11)

In addition, Ariesandi S. (2007) [12] from Surabaya Indonesia Hypnosis Center and a writer of Hypnoparenting book "Menjadi Orangtua Efektif dengan Hipnosis", suggested that hypnosis process is a process of inputing information to the thought. Whereas, parenting is all of the things related to parents' tasks in educationg and raising their children.

As the conclusion, hypnoparenting is an effort done by parents and educators by systematically mapping the things related to parents' tasks based on the how the mind and influence works in order to educate the children to cope with the future

\section{METHOD}

The approach applied in this research was qualitative approach. Qualitative approach is expected to give a deep description about the problem statement to reveal the uniqueness and the distinctiveness of this research [13]. As for the method, it applied study case in Yayasan Anak Langit. Thus regardless of whether a qualitative or quantitative method dominates, its foundation is based on its 'central premise that the use of quantitative and qualitative approaches in combination provides a better understanding of research problems than either approach alone' (Creswell, 2010) [14]. The research's subjects were the trainer/tutor (code: T) as information

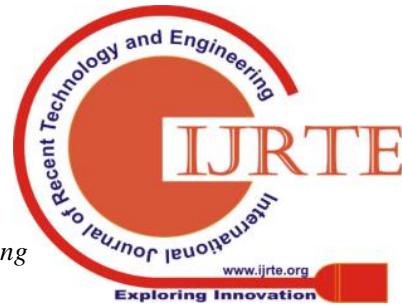


source, and foundation manager $(\mathrm{Y})$, training committee $(\mathrm{P})$, parents (WB), and training alumni (AL) as informan. The instruments of the research were interview guidelines, observation guidelines and documentation study.

\section{RESULT AND DISCUSSIONS}

\section{A.Planning of Hypnoparenting Training}

Overall, training program started from the planning. Planning stage in hynoparenting training ran centralistically and was fully handled by the resource person. As Yehezkel Dror (in Sudjana, 2004, pp. 53) [15]., stated that "Planning is the process of preparing a set of the decision for action in the future directed at achieving goals by preferable means." Since the planning was handled by the resource person, the applied learning model was also carried out by the resource person. As the implementation had already handled technically by hotel, marketing activity to get participants was quite time consuming and costly in the planning stage.

Training need assessment stage was also handled by the resource person spontaneously in the beginning of training along with the ice breaking. Nevertheless, because this activity was a public training, the existence of participants who were willing to register and pay quite expensive indicated that this training was needed. This was relevant with Goad who suggested three important aspects in planning a training program, which were analizing the training needs (Analyze), designing the training approach (Design), and developing the training material (Develop), implementing the training (Implemen), evaluating the training (Evaluate). That was known as EDDIE model. Need assessment was the first stage of a training (Goad, 1996) [16].

Spontaneous and unstructured planning resulted the lack of planning documentation as a reference in the learning implementation, such as lesson plans, syllabi, and guidance. This unstructured planning which was fully handled by the resource person could cause bias in learning needs and goals. Bias was caused by non-involvement of the students in the identification process. Whereas, a good planning is the one which could identify the previous weaknesses and strengths.

\section{B. Implementation of Hypnoparenting Training}

Based on the observation, the implementation of this training applied TANDUR (Tumbuhkan - Growing, Alami Experiencing, Namai - Naming, Demonstrasikan Demonstrating, Ulangi - Repeating, Rayakan - Celebrating) model. As dePorter et.al. (2001), learning flow in the classroom or in a training should follow the pattern known as TANDUR. TANDUR is one of the patten applied in learning targeting the emotional domain or the subconsicuous.

The first stage was growing interest. In this phase, the trainer answered interstingly the question in participants' mind: "What are the benefits for me and for life?" Then, by doing some ice breaking, participant would open their mind.

The second stage was experiencing by telling the parenting problems happened in a family. This kind of bridging model aimed to bridge the learning material and the parenting problems face by parents and their children. It helped parents to easily follow the next learning process. The experiencing process was not only by telling the story or auditorial, but also by visualization with some clips. This was expected to help the participante feel it kinesthetically and connect it to their own obstacles.

The third stage was naming. Naming means providing the keywords, concepts, models, formulas, and strategies as the core of learning.

The fourth stage was demonstrating. Demonstrating was a stage where the trainer challenging the participants to practice what they have learnt. In this training, the parents were called to come forward and the trainer demonstrated some concepts to be applied Sat home.

The fifth stage was repeating. Repeating was a stage to review the learning process, especially the important parts which have been explained. Recalling or repeating in learning was a well-known learning principle to build a new neuron. It made the learning easier. In this phase, the trainer repeated the words and concepts by doing role play, audio-visual, and study case.

The last stage was celebrating. Celebrating was the closing process which was filled by contemplation to reinforce the learning material in participants' subconsciousness. The participants felt the relieveness through the contemplation or relaxation. They also felt happy since they could sing together and got some reward or door prize. This concept will be in the long term memory. According to Rimm, S. (1998, pp. 6), praise is an effective communicator of adult values and is a very important tool for parents (tutors) to guide children (learning citizens). Happiness of parents will be a strong initial motivation. $\backslash[18]$.

\section{Evaluation of Hypnoparenting Training}

The evaluation in this research was only done in the implementation process. It was carried out by the resource person after the learning. Evaluation was handled verbally by direct comments or by written testimony.

Evaluation in the aspect of context or detailed context was not performed by Yayasan Anak Langit. So, the success of the program was not related to the written evaluation. Nevertheless, the organizer had conducted evaluation. Harris W. (in Sudjana, 2004, pp. 249), stated that "the systematic process of judging the worth, desirability, effectiveness, or adequacy of something according to definitive criteria and purposes. As addition, Steele, (1977, pp. 21) [15] [19] said that the judgement is based upon a careful comparison of observation data with criteria standards". Finally, evaluation is a process to make a decision. [20].

\section{Assistance Patter after Training}

The previlage of Yayasan Anak Langit was their incisive assistance after training. Trainer still accepted the consultation schedule to handle the assistance with GROW (Goals-Reality-Option-Will) patterns, where: (1) Goal was to remind the parenting goal, (2) Reality was to describe the objective problems which involved parents' emotion, (3) Option was the alternative solution, and (4) Will was the commitment of parents to apply the solution. The inability of parents in applying the parenting pattern caused by emotion obstacles would be solved by hypnoparenting training which was regularly conducted in Yayasan Anak Langit Bandung. Theoretically, this assistance pattern was known 


\section{Hypnoparenting Training in Improving Parent's Ability About Parenting}

as coaching concept as Carol W. (2011,pp. 7) suggested that performance coaching is a process to help someone find and act based on the solution that suits them the best. Coaching model was developed by Carol W. and named as GROW model. The assistance procedures are started from Goal, Reality, Option, and Will.

\section{CONCLUSION}

The research conducted by Yayasan Anak Langit had applied managerial functions, which are planning, implementation, evaluation, and assistance after the training by using coaching concept. Nevertheless, there was some stages that should be handled by professionally. Professional means the program have to be systematic, structured, and well-documented as a training management system in order to be independent. As the result, this training program cannot be continued without the trainer. An accurate and completed data about the program were very substantial. Data are the energy to prove the benefits of the program to people or institution.

\section{ACKNOWLEDGMENT}

We would like to express our deepest gratitude to Department of Community Education for the research opportunity. We would like to also appreciate Yayasan Anak Langit as the partner who has helped the research from the beginning till its completion.

\section{REFERENCES}

1. Undang-Undang No 20 Tahun 2003 tentang Sistem Pendidikan Nasionl

2. Ath-Thabrani, S.A.. Al-Mu 'jam al-Kabir. al Mushil: Maktabah al Ulum wa al-Hikam.1983

3. Sirait, A.M. Waspada, Jumlah Anak Stres Semakin Meningkat [Online]. Diakses dari http://www.psikologizone.com, 2012.

4. Mushaf Al-Qur'anulkarim, Miracle The Reference. Bandung: PT Sygma Examedia Arkanleema, 2010.

5. Lickona, T.. Characeter Matters: Persoalan karakter. Jakarta: PT. Bumi Aksara. 2012

6. Greenberg, M. Worst Mistakes Parents Make When Talking to Kids. [Online]. Diakses dari http://www.psychologytoday.com. 2012.

7. Spooky. Hypno-Parenting - How One Hypnotherapist Use Hypnosis to Manage Her Kids'Behavior. Obtained on $20^{\text {th }}$ November, 2017 from http://www.odditycentral.com/news/hypno-parenting-how-one-hypnoth erapist-uses-hypnosis-to-manage-her-kids-behavior.html, By Spooky on July 29th, 2016 Category: News.

8. Wehbe J, Safar Y. Hypnosis and Physiotherapy. Kinesither Rev (2015), http://dx.doi.org/ 10.1016/j.kine.2015.06.007

9. Eslinger MR. Hypnosis principles and applications: an adjunct to health care. CRNA 2000;11:190-6. 2005.

10. Newmark TS, (2005). Bogacki DF. The use of relaxation, hypnosis, and imagery in sport psychiatry. Clin Sports Med 2005;24:973-7 [xi] 2005

11. Dr Ran D.Anbar, (2006). Journal Of Pediatric : Hypnosis “An Important Multifaceted Therapy". Department of Pediatrics, SUNY Upstate Medical University, 750 E. Adams St., Syracuse, NY 13210. E-mail: anbarr@upstate.edu. Journal of Pediatr 2006;149:438-9

12. Ariesandi, S. Hypnoparenting. Jakarta: PT. Gramedia. 2006.

13. Sugiono. Metode Penelitian Kualitatif dan Kuantitatif. Bandung: CV. Alfabeta. 2011.

14. Creswell W. J. Qualitative Inquiry And Reseach Design Choosing Among Five Traditions. London, New Delhi: Sage Publications. 2010.

15. Sudjana, D. Pendidikan Luar Sekolah, Wawasan Sejarah Perkembangan Falsafah Teori Pendukung Asas. Bandung: Falah Production. 2004

16. Goad, W. T. Delivering Effective Training. San Diago Califronia: University Associates.1996.
17. DePorter, B, dkk. Quantum Teaching: Mempraktikkan Quantum Learning di Ruang-Ruang Kelas. Jakarta: kaifa (Mizan Group). 2010.

18. Rimm, S. Mendidik dan Menerapkan Disiplin pada Anak Prasekolah. Jakarta: PT. Gramedia Pustaka Utama. 2003.

19. Steel, S. M. Contemporary Approaches to Program Evaluation Washington: Capital Publication.1977.

20. Knox, A.B.. Developing, Administering, and Evaluating Adult Education. Sans Francisco: Jossey-Bass Publishers. 1980

\section{AUTHORS PROFILE}

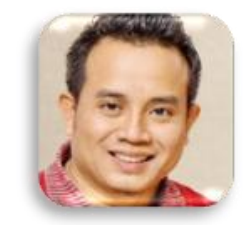

Wasmin, doctoral student at

Community Education Department, Universitas Pendidikan Indonesia. Researcher and Motivator Hypnoparenting Training Bandung City.

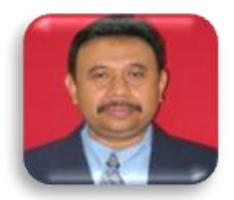

Achmad Hufad, Professor at community education Department, Universitas Pendidikan Indonesia. Researcher in Social Sciences and Cultures.

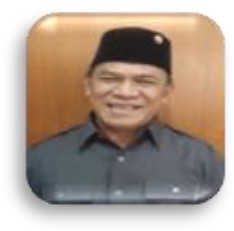

Ace Suryadi, Professor at Community Education Department, Universitas Pendidikan Indonesia. Researcher in Policy education and Economic. Education consultant at government agency.

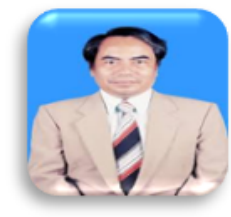

Oong Komar, Professor at Community Education Department, Universitas Pendidikan Indonesia. Reasearcher in Philosophi, Sertification, and community empowerment in Community Education.

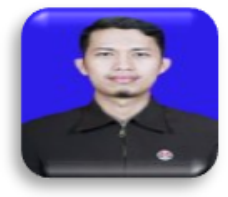

Dadang Yunus Lutfiansyah, Lecture at Community Education Department, Universitas Pendidikan Indonesia. Researcher in Empowering, Andragogy, Trainning and Community Education. 